\title{
Kebersihan makanan dan hand hygiene sebagai faktor resiko demam tifoid di Bandar Jaya, Lampung
}

\author{
Eka Trismiyana $^{1 *}$, Leni Yulinda Kesuma Agung ${ }^{2}$
}

${ }^{1}$ Program DIII Keperawatan Fakultas Kedokteran Universitas Malahayati

^Email: ekatrismiyana@gmail.com

2Puskesmas Bandar Jaya Lampung Tengah. Email: leniyulinda2307@gmail.com

\section{Abstract \\ Poor food hygiene and hand hygiene as risk factors for typhoid fever in Bandar Jaya, Lampung}

Background: Typhoid fever is still a public health problem with as many as 22 million cases per year in the world and causes 216,000-600,000 deaths. Typhoid fever in Indonesia increases from year to year with an average illness of $500 / 100,000$ populations and a mortality rate of $0.6-5 \%$. The incidence of typhoid fever in Lampung Province in 2018 was 37,708 people, an increase compared to 2017 which was 32,896 patients. Data from the Central Lampung Health authority in 2018, typhoid fever in Public health centre reached 3,415 people. While the highest prevalence of 37 public health centre in Central Lampung was in Bandar Jaya Health Center as many as 133 people. One of the things that can trigger this disease is food and hand hygiene factors.

Purpose: Knowing of poor food hygiene and hand hygiene as risk factors for typhoid fever in Bandar Jaya, Lampung

Method: A quantitative study with a design by case control. The research subjects were patients who had a fever at Bandar Jaya Health Centre in Central Lampung, with 80 respondents divided by 2 groups; 40 respondents (cases) and 40 respondents as control. Data analysis in this study used the chi-square test.

Results: Most of the respondents never washed their hands before eating, as much as $72.5 \%$ and taking food from outside (unhygienic) $72.5 \%$. There have not a relationship between unhygienic food and hand hygiene as a risk factor for typhoid fever in Bandar Jaya, Lampung ( $p$-value $=0.639, O R=1.2314,286$ ); hand hygiene and typhoid fever ( $p$-value $=0.809, \mathrm{OR}=1.24)$.

Conclusion: There have not a relationship between unhygienic food and hand hygiene as a risk factor for typhoid fever. It needs to further improve health promotion about good eating habits and good hand hygiene in the community.

\section{Keywords: Poor food hygiene; Hand hygiene; Risk factors; Typhoid fever}

Pendahuluan: Demam tifoid masih merupakan masalah kesehatan masyarakat dengan jumlah kasus sebanyak 22 juta per tahun di dunia dan menyebabkan 216.000-600.000 kematian. Demam tifoid di Indonesia menunjukkan kecenderungan meningkat dari tahun ke tahun dengan rata-rata kesakitan 500/100.000 penduduk dan angka kematian antara 0,6-5\%. Angka kejadian demam tifoid di Provinsi Lampung tahun 2018 adalah 37.708 orang, meningkat dibandingkan pada tahun 2017 yaitu sebanyak 32.896 pasien. Data Dinas Kesehatan Lampung Tengah tahun 2018, demam tifoid di Puskesmas mencapai 3.415 orang. Sedangkan prevalensi tertinggi dari 37 Puskesmas di Lampung Tengah terdapat di Puskesmas Bandar Jaya sebanyak 133 orang. Salah satu hal yang dapat memicu timbulnya penyakit ini adalah dari makanan dan hand hygiene yang kurang baik.

Tujuan: Diketahui hubungan kebersihan makanan dan hand hygiene sebagai faktor resiko demam tifoid di Bandar Jaya, Lampung

Metode: Penelitian kuantitatif dengan desain case control. Subjek penelitian adalah pasien demam di Puskesmas Bandar Jaya Lampung Tengah sebanyak 80 responden yang terbagi dalam 2 kelompok; 40 responden (kasus) dan 40 responden sebagai kontrol. Analisis data dalam penelitian ini menggunakan uji chisquare.

Hasil: Sebagian besar responden tidak pernah mencuci tangan sebelum makan, sebanyak $72,5 \%$ dan jajan makanan dari luar (tidak higienis) $72,5 \%$. Tidak ada hubungan antara makanan tidak higienis dengan kebersihan tangan sebagai faktor risiko terjadinya demam tifoid di Bandar Jaya Lampung ( $p$-value $=0.639, \mathrm{OR}=1.23$ ); kebersihan tangan dan demam tifoid ( $p$-value $=0.809, \mathrm{OR}=1.24$ ). 
Simpulan: Tidak ada hubungan antara makanan yang tidak higienis dan kebersihan tangan sebagai faktor risiko terjadinya demam tifoid. Perlu lebih meningkatkan promosi kesehatan tentang kebiasaan makan yang baik dan kebersihan tangan yang baik di masyarakat.

\section{Kata Kunci: Demam tifoid; Kebersihan makanan; Hand hygiene}

\section{PENDAHULUAN}

Angka kesakitan dan kematian penyakit merupakan indikator dalam menilai derajat kesehatan suatu masyarakat. Pengendalian penyakit merupakan upaya penurunan insidens, prevalensi, morbiditas atau mortalitas dari suatu penyakit hingga level yang dapat diterima secara lokal. Penyakit menular masih manjadi masalah di Indonesia. Penyakit menular meliputi penyakit menular langsung, penyakit yang dapat dikendalikan dengan imunisasi dan penyakit yang ditularkan melalui binatang. Penyakit menular diantaranya tuberculosis paru, HIV, pneumonia, kusta, diare, tifoid, tetanus, campak, difteri, polio, demam berdarah dangue (DBD), cikungunya, filariasis, malaria, rabies, leptospirosis, antraks, dll (Kementerian Kesehatan Republik Indonesia, 2017).

Salah satu penyakit menular adalah demam tifoid. Demam tifoid masih sering terjadi di negara berkembang. Demam tifoid dapat disebabkan beberapa serovar Salmonella enterica termasuk $S$. typhi dan S. paratyphi A. Walaupun secara global $S$. typhi merupakan penyebab utama, infeksi $S$. paratyphi $A$ juga terjadi di beberapa bagian dunia (Hadinegoro, Kadim, Devaera, Idris, \& Ambarsari, 2012).

Demam tifoid masih merupakan masalah kesehatan masyarakat dengan jumlah kasus sebanyak 22 juta per tahun di dunia dan menyebabkan 216.000-600.000 kematian. Studi yang dilakukan di daerah urban di beberapa negara Asia menunjukkan bahwa insidensi dengan biakan darah positif mencapai 180-194 per 100.000, di Asia Selatan sebesar $400-500$ per 100.000 penduduk, di Asia Tenggara 100-200 per 100.000 penduduk, dan di Asia Timur Laut kurang dari 100 kasus per 100.000 penduduk (Crump, Luby, \& Mintz, 2004; Elisabeth Purba, Wandra, Nugrahini, Nawawi, \& Kandun, 2016).

Demam tifoid di Indonesia bersifat endemik dan merupakan masalah kesehatan masyarakat. Berdasarkan telah kasus di rumah sakit besar di Indonesia, tersangka demam tifoid menunjukkan kecenderungan meningkat dari tahun ke tahun dengan rata-rata kesakitan 500/100.000 penduduk dan angka kematian antara 0,6-5\% (Kementerian
Kesehatan Republik Indonesia, 2014). Selain itu demam tifoid juga menempati urutan ke-3 dari 10 penyakit terbanyak pasien rawat inap di rumah sakit yaitu sebanyak 41.081 kasus, yang meninggal 274 orang dengan Case Fatality Rate sebesar 0,67\% (Budiyanto, 210; Masnawati, 2014).

Angka kejadian demam tifoid di Provinsi Lampung tahun 2018 menyebutkan bahwa jumlah pasien yang dirawat inap akibat demam tifoid di puskesmas adalah 37.708 orang, di rumah sakit rawat jalan 210 orang dan rawat inap 96 orang. Jumlah ini meningkat dibandingkan pada tahun 2017 yaitu sebanyak 32.896 pasien puskesmas, di rumah sakit rawat jalan 187 orang dan rawat inap 92 orang (Dinas Kesehatan Provinsi Lampung, 2018).

Demam tifoid merupakan penyakit infeksi yang prevalensinya cukup tinggi, dimana angka kejadiannya di Puskesmas mencapai 3.415 orang. Sedangkan prevalensi tertinggi dari 37 Puskesmas di Lampung Tengah terdapat di Puskesmas Bandar Jaya sebanyak 133 orang, Puskesmas Gaya Baru Lima sebanyak 122 orang, dan Puskesmas Seputih Banyak sebanyak 116 orang (Dinas Kesehatan Lampung Tengah, 2018).

Demam tifoid merupakan gastrointestinal infection yang disebabkan oleh $S$. typhi dan S.paratyphi yang banyak ditemukan di masyarakat perkotaan maupun di pedesaan yang dikaitkan dengan kualitas higiene pribadi dan sanitasi lingkungan yang kurang baik (Kementerian Kesehatan Republik Indonesia, 2014).

Dampak dari penyakit demam tifoid antara lain dapat menyebabkan komplikasi yang terjadi pada 10\%-15\% kasus yang menderita penyakit lebih dari 2 minggu. Komplikasi yang sering terjadi yaitu perforasi saluran cerna $(10 \%)$ dan ensefalopati tifoid (10-40\%) (Hadinegoro, Kadim, Devaera, Idris, \& Ambarsari, 2012). Selain itu, komplikasi biasanya terjadi pada minggu kedua dan ketiga demam. Komplikasi antara lain perdarahan, perforasi, sepsis, ensefalopati, dan infeksi organ lain (Kementerian Kesehatan Republik Indonesia, 2014).

Faktor epidemiologi penyebab penyakit infeksi termasuk demam tifoid diantaranya adalah agentagent infeksi (penyebab infeksi), sumber infeksi dan

Eka Trismiyana" Program DIIl Keperawatan Fakultas Kedokteran Universitas Malahayati Email: ekatrismiyana@gmail.com Leni Yulinda Kesuma Agung', Puskesmas Bandar Jaya Lampung Tengah. Email: leniyulinda2307@gmail.com 
penyebaran penyakit, dan faktor induk semang (host) (Syafrudin, 2009). Faktor induk semang (host) meliputi hand hygiene, makanan, sanitasi lingkungan yang kumuh dan imunitas (Kementerian Kesehatan Republik Indonesia, 2006).

Salah satu hal yang dapat memicu timbulnya penyakit ini adalah dari makanan yang kurang baik. Makanan merupkan suatu yang dikonsumsi umumnya terdiri atas satu atau beberapa jenis bahan makanan dan dapat diperoleh dari berbagai sumber dan bentuk (Santoso, \& Ranti, 2013). Kebiasaan konsumsi makanan yang baik dengan konsumsi makanan yang sehat dan teratur, sedangkan kebiasaan makan dapat menyebabkan timbulnya penyakit tifoid yaitu kebiasaan makan yang tidak teratur dan menyantap makanan yang kurang bersih. Hal ini bisa terjadi dikarenakan oleh kebiasaan-kebiasaan seperti membeli makanan di warung-warung yang kurang terjaga kebersihannya (Masnawati, 2014).

Selain itu, faktor yang dapat menjadi penyebab demam tifoid adalah kurangnya kebersihan tangan atau hand hygiene. Mencuci tangan sesudah buang air besar, mencuci tangan sebelum makan akan melindungi seseorang dari infeksi penyakit kemudian kondisi kuku jari tangan seseorang juga mempengaruhi terjadinya demam tifoid. Mencuci tangan (hand hygiene) yang baik yaitu harus menggunakan sabun serta air yang mengalir karena menggosok sela-sela jari dan kuku dapat mencegah bakteri yang berada di kuku jari tangan (Rakhman, 2009; Nuruzzaman, \& Syahrul, 2016).

Analisis risiko kejadian demam tifoid berdasarkan kebersihan diri dan kebiasaan jajan di rumah diperoleh bahwa terdapat hubungan demam tifoid dengan kebiasaan mencuci tangan sebelum makan yang kurang baik di rumah $\mathrm{OR}=4,33 ; 95 \%$ $\mathrm{Cl}(1,54<\mathrm{OR}<12,44)$, serta terdapat hubungan demam tifoid dengan sering jajan saat di rumah $\mathrm{OR}$ $=3,89 ; 95 \% \mathrm{Cl}(1,39<\mathrm{OR}<11,06)$ (Nuruzzaman, \& Syahrul, 2016).
Salah satu puskesmas dengan kasus demam tifoid yang tinggi dan sebagian besar terjadi pada orang dewasa yaitu Puskesmas Bandar Jaya, selain itu ada kecenderungan peningkatan angka kejadian dari tahun sebelumnya. Pada tahun 2016 jumlah pasien demam tifoid mencapai 107 orang, meningkat pada tahun 2017 menjadi 121 orang, dan kembali meningkat pada tahun 2018 menjadi 133 orang (Dinas Kesehatan Lampung Tengah, 2018). Hasil wawancara peneliti terhadap 10 orang pasien yang pernah mengalami tifoid, sebanyak 8 orang $(80 \%)$ mengatakan kurang memperhatikan kebiasaan makan yang sehat seperti makan kurang dari 3 kali sehari dan seringnya membeli makanan diluar rumah yang belum tentu terjaga kebersihannya, jarang mencuci tangan sebelum makan.

\section{METODE PENELITIAN}

Jenis penelitian kuantitatif. Rancangan dengan case control. Penelitian ini sudah lulus kelaikan etik dari Komisi Etik Penelitian Kesehatan Universitas Malahayati dan dilaksanakan di Puskesmas Bandar Jaya Lampung Tengah pada bulan Juni 2019. Populasi seluruh pasien yang mengalami demam sebanyak 172 orang dan jumlah sampel kasus sebanyak 40 orang ditambah dengan jumlah sampel control sebanyak 40 orang, sehingga jumlah keseluruhan sampel adalah 80 sampel. Teknik sampling yang digunakan simple random sampling.

Alat pengumpulan data berupa kuesioner yang berisi pertanyaan tentang makanan sebanyak 10 soal dan hand hygiene sebanyak 10 soal. Data diambil dan dikumpulkan langsung dari responden dengan melakuan wawancara dan data rekam medik pasien. Kemudian hasil perolehan dicatat dan didokumentasikan untuk selanjutnya dilakukan pengolahan data. Dalam analisis ini menggunakan pengujian statistik rumus chi-square dengan taraf yang digunakan adalah $5 \%$ atau $p$-value 0,05 . 


\section{HASIL}

Tabel 1. Distribusi Frekuensi Karakteristik Responden Terhadap Kejadian Demam Tifoid N=80

\begin{tabular}{|c|c|c|c|c|}
\hline Distribusi frekuensi karakteristik & Kasus $n=40$ & Control $n=40$ & p-value & OR $(95 \% \mathrm{Cl})$ \\
\hline 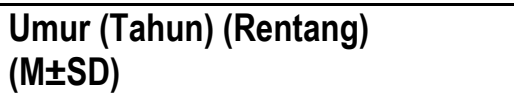 & $\begin{array}{c}34.34 \pm 34.00 \\
(21-49)\end{array}$ & $\begin{array}{c}34.34 \pm 34.00 \\
(21-49)\end{array}$ & 0.614 & \\
\hline \multicolumn{5}{|l|}{ Jenis Kelamin: } \\
\hline - Laki-laki & 23 & 27 & 0.644 & 0.808 \\
\hline - $\quad$ Perempuan & 17 & 13 & & $(0.32-2.00)$ \\
\hline \multicolumn{5}{|l|}{ Pendidikan } \\
\hline$-\quad S D$ & 23 & 27 & 0.830 & \\
\hline - SMP & 8 & 7 & & \\
\hline - SMA & 5 & 5 & & \\
\hline - $\quad$ Perguruan tinggi & 4 & 1 & & \\
\hline \multicolumn{5}{|l|}{ Pekerjaan } \\
\hline - Buruh & 12 & 18 & 0.821 & \\
\hline - Karyawan & 10 & 10 & & \\
\hline - $\quad$ PNS & 4 & 1 & & \\
\hline - Tani & 6 & 4 & & \\
\hline - Wiraswasta & 8 & 7 & & \\
\hline
\end{tabular}

Berdasarkan hasil penelitian diketahui bahwa ada hubungan antara frekuensi karakteristik terjadinya kejadian demam thypoid terhadap personal hygine terhadap masyarakat \pm 0.808 lebih beresiko jika terhadap jenis kelamin . 
Tabel 2. Faktor-Faktor Yang Berhubungan Dengan Kejadian Demam Tifoid N=80

\begin{tabular}{|c|c|c|c|c|}
\hline Faktor Terjadinya Demam Typhoid & $\begin{array}{c}\text { Kasus } \% \\
n=40\end{array}$ & $\begin{array}{c}\text { Kontrol \% } \\
n=40\end{array}$ & $p$-value & $\mathrm{OR}(95 \% \mathrm{Cl})$ \\
\hline \multicolumn{5}{|l|}{ Kualitas air mandi } \\
\hline - Baik & $14(35 \%)$ & $26(65 \%)$ & \multirow[t]{3}{*}{0.639} & 1.24 \\
\hline - Buruk & $26(65 \%)$ & $14(35 \%)$ & & $(0.49-3.19)$ \\
\hline \multicolumn{4}{|l|}{ Kualitas air gosok gigi } & \\
\hline - Baik & $16(40 \%)$ & $24(60 \%)$ & \multirow[t]{2}{*}{0.648} & 1.23 \\
\hline - Buruk & $24(60 \%)$ & $16(40 \%)$ & & $(0.5-3.01)$ \\
\hline \multicolumn{5}{|l|}{ Kualitas air cuci tangan } \\
\hline - Baik & $12(30 \%)$ & $38(70 \%)$ & \multirow[t]{3}{*}{0.626} & 0.78 \\
\hline - Buruk & $38(70 \%)$ & $12(30 \%)$ & & $(0.30-2.05)$ \\
\hline \multicolumn{4}{|l|}{ Kualitas air untuk minum } & \\
\hline - Baik & $11(27.5 \%)$ & $29(72.5 \%)$ & \multirow[t]{3}{*}{0.317} & 1.65 \\
\hline - Buruk & $29(72.5 \%)$ & $11(27.5 \%)$ & & $(0.61-4.48)$ \\
\hline \multicolumn{4}{|l|}{ Kontaminasi bakteri E.Coli untuk minum } & \\
\hline$-\mathrm{Ya}$ & $23(57.5 \%)$ & $17(42.5 \%)$ & \multirow[t]{2}{*}{0.651} & 0.81 \\
\hline - Tidak & $17(42.5 \%)$ & $23(57.5 \%)$ & & $(0.33-1.98)$ \\
\hline \multicolumn{5}{|l|}{ Pasokan air rumah } \\
\hline - Pasokan air (PDAM/Pam) & $14(35 \%)$ & $26(65 \%)$ & \multirow[t]{3}{*}{0.639} & 1.24 \\
\hline - Sumber lain & $26(65 \%)$ & $14(35 \%)$ & & $(0.14-3.12)$ \\
\hline \multicolumn{4}{|l|}{ Pembuangan limbah rumah } & \\
\hline - Drainase tertutup & $6(15 \%)$ & $34(85 \%)$ & \multirow{3}{*}{1.00} & 1.00 \\
\hline - Drainase terbuka & $34(85 \%)$ & $6(15 \%)$ & & $(0.29-3.41)$ \\
\hline \multicolumn{4}{|l|}{ Lantai ruang tamu terbuat dari } & \\
\hline - Ubin & $26(65 \%)$ & $14(35 \%)$ & \multirow[t]{2}{*}{0.639} & 1.24 \\
\hline - Tanah atau semen & $14(35 \%)$ & $26(65 \%)$ & & $(0.49-3.12)$ \\
\hline \multicolumn{5}{|l|}{ Lantai dapur terbuat dari } \\
\hline - Ubin & $14(35 \%)$ & $26(65 \%)$ & \multirow[t]{2}{*}{0.639} & 1.24 \\
\hline - Tanah atau semen & $26(65 \%)$ & $14(35 \%)$ & & $(0.49-3.12)$ \\
\hline \multicolumn{3}{|l|}{ Pencucian tangan sebelum makan } & \multirow[t]{3}{*}{0.809} & 1.23 \\
\hline - Selalu & $11(27.5 \%)$ & $26(65 \%)$ & & $(0.43-2.89)$ \\
\hline - Tidak pernah & $29(72.5 \%)$ & $14(35 \%)$ & & \multirow{4}{*}{$\begin{array}{c}1.47 \\
(0.54-4.02)\end{array}$} \\
\hline \multicolumn{3}{|l|}{$\begin{array}{l}\text { Mencuci tangan sebelum menyiapkan } \\
\text { makan }\end{array}$} & \multirow[t]{3}{*}{0.446} & \\
\hline - Selalu & $10(25 \%)$ & $29(72.5 \%)$ & & \\
\hline - Tidak pernah & $30(75 \%)$ & $11(27.5 \%)$ & & \\
\hline \multicolumn{3}{|l|}{ Kebiasaan jajan makanan diluar } & \multirow[t]{3}{*}{0.639} & 1.24 \\
\hline - Tidak pernah & $14(35 \%)$ & $26(65 \%)$ & & $(0.49-3.12)$ \\
\hline - 1 kali per minggu & $26(65 \%)$ & $14(35 \%)$ & & \\
\hline Kondisi restoran atau warung makanan & & & 0.805 & 1.13 \\
\hline - Rumah makan tertutup & $11(27.5 \%)$ & $28(70 \%)$ & & $(0.42-2.97)$ \\
\hline - Warung jalanan & $29(72.5 \%)$ & $12(30 \%)$ & & \\
\hline Kebiasaan minum dengan ES batu & & & 0.617 & 1.28 \\
\hline - Tidak pernah & $8(20 \%)$ & $26(65 \%)$ & & $(0.48-3.44)$ \\
\hline - lya & $32(80 \%)$ & $14(35 \%)$ & & \\
\hline
\end{tabular}

Berdasarkan hasil penelitian diketahui bahwa tidak ada hubungan antara faktor pemicu terjadinya kejadian demam thypoid terhadap personal hygine terhadap masyarakat . sedangkan kualitas air untuk minum pada masyarakat \pm 1.65 kali lebih beresiko terhadap kejadian demam tifoid.

Eka Trismiyana" Program DIIl Keperawatan Fakultas Kedokteran Universitas Malahayati Email: ekatrismiyana@gmail.com Leni Yulinda Kesuma Agung², Puskesmas Bandar Jaya Lampung Tengah. Email: leniyulinda2307@gmail.com 
Kebersihan makanan dan hand hygine dengan kejadian tifoid

\section{PEMBAHASAN \\ Kebersihan Makanan}

Berdasarkan hasil penelitian diperoleh bahwa sebagian besar responden sering jajan makanan diluar, yaitu sebanyak $72,5 \%$. Hasil penelitian sejalan dengan teori bahwa makanan dikonsumsi umumnya terdiri atas satu atau beberapa jenis bahan makanan dan dapat diperoleh dari berbagai sumber dan bentuk, sebagai contoh telur, daging, ubi, sayur dan sebagainya. Makanan bagi manusia merupakan kebutuhan pokok yang harus dipenuhi untuk dapat mempertahankan hidup serta menjalankan kehidupan (Santoso, \& Ranti, 2013).

Sejalan dengan penelitian sebelumnya bahwa hasil analisis univariat diperoleh sebagian besar responden yaitu $33(66 \%)$ membeli makanan untuk dikonsumsi dan hanya $17(34 \%)$ responden yang mengolah sendiri makanannya (Nadyah, 2013).

Menurut analisis peneliti sebagian besar responden memiliki makanan dalam kategori tidak baik disebabkan karena berbagai faktor. Baik atau tidak baiknya seseorang dalam memilih makanan biasanya tergantung dari kepedulian mereka dalam menjaga kesehatan, orang yang peduli akan kesehatan akan cenderung untuk memilih makanan yang lebih hygienis dan memenuhi nilai gizi yang baik. Berdasarkan hasil jawaban kuesioner penelitian, sebanyak 30 orang yang mengkonsumsi makanan yang tidak di masak sendiri dan tidak mengkonsumsi buah-buahan sebagian besar ternyata memiliki tingkat pendidikan yang rendah. Untuk itu seharusnya dalam memilih jenis makanan harus mengurangi jajan dan makan di warungwarung pinggir jalan dan sebaiknya memakan makanan yang dimasak sendiri dirumah.

\section{Hand Hygiene}

Berdasarkan hasil penelitian diperoleh bahwa sebagian besar responden tidak melakukan cuci tangan sebelum makan sebanyak $72.5 \%$.

Penelitian ini sejalan dengan teori bahwa hand hygiene merupakan suatu kegiatan melakukan cuci tangan memakai sabun yang dilakukan untuk mencegah penyakit yang dapat menyebabkan infeksi (Anik, 2013).

Sejalan dengan penelitian sebelumnya bahwa hasil analisis univariat diperoleh bahwa kebiasaan mencuci tangan sebelum makan yang tidak baik (tidak menggunakan air mengalir dan sabun) saat berada di rumah sebagian besar terdiagnosis demam tifoid yakni sebesar 65\% (Nuruzzaman, \& Syahrul, 2016).

Menurut analisis peneliti sebagian besar responden memiliki hand hygiene tidak baik disebabkan karena pengetahuan dan kesadaran responden yang tidak baik dalam menjaga kesehatan. Hasil jawaban kuesioner terhadap responden didapatkan bahwa sebagian besar responden yang tidak melakukan hand hygiene dengan baik seperti tidak mencuci tangan sebelum makan dan menyiapkan makanan, setelah mengganti popok dan menceboki anak, ketika pulang ke rumah, dan setelah membuang sampah. Kebanyakan mereka juga jarang menggunakan sabun ketika mencuci tangan.

\section{Kejadian Demam Tifoid}

Berdasarkan hasil penelitian diperoleh bahwa responden mengalami dan tidak mengalami demam tifoid sama banyaknya yaitu masing-masing sebanyak $50 \%$.

Hasil penelitian sejalan dengan teori bahwa demam tifoid merupakan gastrointestinal infection yang disebabkan oleh S. typhi dan S.paratyphi yang banyak ditemukan di masyarakat perkotaan maupun di pedesaan yang dikaitkan dengan kualitas higiene pribadi dan sanitasi lingkungan yang tidak baik (Kementerian Kesehatan Republik Indonesia, 2014).

Sejalan dengan penelitian lainnya bahwa hasil analisis univariat diperoleh bahwa kebiasaan mencuci tangan sebelum makan yang tidak baik (tidak menggunakan air mengalir dan sabun) saat berada di rumah sebagian besar terdiagnosis demam tifoid yakni sebesar $65 \%$. Selain itu, anak terdiagnosis menderita demam tifoid sebagian besar memiliki frekuensi sering jajan saat berada di rumah yaitu sebesar 55\% (Nuruzzaman, \& Syahrul, 2016).

Menurut analisis peneliti responden mengalami dan tidak mengalami demam tifoid sama banyaknya disebabkan karena peneliti menggunakan jenis penelitian case control dengan mengambil kasus yaitu penderita demam tifoid dan kontrol yaitu yang tidak menderita demam tifoid. Berdasarkan jawaban dari kuesioner makanan dapat menjadi penyebab demam tifoid, responden yang cenderung mengalami penurunan nafsu makan kebanyakan mengalami demam tifoid. Kemudian juga faktor hand hygiene terutama tidak mencucu tangan setelah kontak dengan hewan peliharaan menjadi

Eka Trismiyana" Program DIIl Keperawatan Fakultas Kedokteran Universitas Malahayati Email: ekatrismiyana@gmail.com Leni Yulinda Kesuma Agung'2, Puskesmas Bandar Jaya Lampung Tengah. Email: leniyulinda2307@gmail.com 
hal yang paling tersering pada penderita demam tifoid. Hal tersebut karena penyebab demam tifoid itu sendiri antara lain dari makanan yang tidak baik misalnya pada makanan yang kurang terjamin kebersihannya sehingga kuman Salmonella Typhi dapat masuk kedalam saluran pencernaan melalui makanan yang terkontaminasi kuman tersebut. Selain itu, demam tifoid juga dapat terjadi akibat kebiasaan hand hygiene yang tidak baik.

\section{Hubungan Kebersihan Makanan Dengan Kejadian Demam Tifoid}

Berdasarkan hasil penelitian diperoleh bahwa tidak ada hubungan makanan dengan kejadian demam tifoid $(p$-value $=0.639$ dan $O R=1.24)$. Sesuai dengan teori bahwa demam tifoid disebarkan melalui jalur fecal-oral dan hanya menginfeksi manusia yang mengkonsumsi makanan atau minuman yang terkontaminasi oleh bakteri Salmonella typhi (Mansjoer, 2001; Nadyah, 2013).

Hasil analisis bivariat penelitian terdahulu diperoleh ada hubungan kebiasaan makan dengan kejadian tifoid dengan $p$-value $=0,000$ (Masnawati, 2014). Selain itu hasil penelitian lain diperoleh bahwa risiko demam tifoid dengan sering jajan saat di rumah $\mathrm{OR}=3,89 ; 95 \% \mathrm{Cl}(1,39<\mathrm{OR}<11,06)$ (Nuruzzaman, \& Syahrul, 2016).

Menurut analisis peneliti adanya hubungan makanan dengan kejadian demam tifoid disebaban karena makanan merupakan jalan kuman penyebab demam tifoid untuk masuk kedalam tubuh seseorang dan menginfeksi orang tersebut. Hal ini sesuai dengan hasil yang diperoleh dimana responden yang tidak mengalami demam tifoid cenderung memiliki makanan dalam kategori baik $(77,4 \%)$. Selain itu responden yang mengalami demam tifoid juga cenderung memiliki makanan dalam kategori tidak baik $(80,6 \%)$. Makanan yang tidak baik seperti sering makan tidak tepat waktu, jajan di warung, kurangnya knsumsi buah-buahan dan mengkonsumsi makanan yang tidak dimasak sendiri merupakan kebiasaan makan yang tidak baik. Hal ini selain dapat menjadi sumber infeksi karena kebersihannya kurang baik, sering juga menimbulkan masalah gizi yang tidak seimbang, dimana jajanan atau makanan di luar selain tidak terjamin kebersihannya juga tidak terjamin nilai gizinya. Kurangnya akan zat atau nutrien yang diperlukan tubuh mengakibatkan melemahnya daya tahan tubuh seseorang sehingga mudah terserang penyakit, terlebih lagi jika sebelumnya pernah mengalami demam tifoid yang artinya masih ada sebagian kuman Salmonella thypi yang masih berada didalam tubuh namun tidak menimbulkan gejala. Kuman tersebut dapat berkembang jika daya tahan tubuh melemah.

Hasil penelitian diperoleh sebagian responden yang memiliki makanan dalam kategori tidak baik namun tidak mengalami demam tifoid $(22,6 \%)$. Selain itu, sebagian responden yang memiliki makanan dalam kategori baik namun mengalami demam tifoid $(19,4 \%)$. Hal ini dikarenakan demam tifoid dipengaruhi oleh faktor lain selain makanan, misalnya yaitu demam tifoid dipengaruhi oleh kebiasaan hand hygiene responden, dimana kemungkinan yang mengalami demam tifoid memiliki hand hygiene yang tidak baik. Selain itu faktor sanitasi lingkungan juga dapat mempengaruhi demam tifoid.

\section{Hubungan Hand Hygiene Dengan Kejadian Demam Tifoid}

Berdasarkan hasil penelitian diperoleh bahwa ada hubungan hand hygiene dengan kejadian demam tifoid $p$-value $=0.809, \mathrm{OR}=1.24$. Hasil penelitian ini tidak sejalan dengan teori bahwa faktor yang dapat menjadi penyebab demam tifoid adalah kurangnya kebersihan tangan atau hand hygiene. Kebersihan diri salah satu penularan dari penyakit saluran pencernaan adalah melalui tangan yang tercemar oleh mikroorganisme yang merupakan penyebab penyakit (Rakhman, 2009; Nuruzzaman, \& Syahrul, 2016).

Sejalan dengan penelitian lainnya dimana hasil analisis bivariat diperoleh ada hubungan personal hygiene dengan kejadian demam tifoid pada anak $(p$-value $=0,000)$ (Zulfian, \& Rafie, 2014). Selain itu, hasil penelitian sebelumnya bahwa hasil analisis bivariat diperoleh bahwa besar risiko demam tifoid dengan kebiasaan mencuci tangan sebelum makan yang kurang baik di rumah $\mathrm{OR}=4,33 ; 95 \% \mathrm{Cl}(1,54$ $<$ OR < 12,44) (Nuruzzaman, \& Syahrul, 2016).

Menurut analisis peneliti adanya hubungan hand hygiene dengan kejadian demam tifoid disebabkan karena hand hygiene merupakan salah satu kegiatan yang dapat mengeliminasi kuman penyebab demam tifoid sehingga kuman tersebut tidak masuk kedalam tubuh. Hal ini sesuai dengan hasil yang diperoleh dimana responden yang tidak mengalami demam tifoid cenderung memiliki hand hygiene dalam kategori baik $(58,1 \%)$. Selain itu responden yang mengalami demam tifoid juga cenderung memiliki hand hygiene dalam kategori tidak baik $(77,4 \%)$. Responden yang menderita demam tifoid cenderung memiliki kebiasaan yang

Eka Trismiyana" Program DIIl Keperawatan Fakultas Kedokteran Universitas Malahayati Email: ekatrismiyana@gmail.com Leni Yulinda Kesuma Agung², Puskesmas Bandar Jaya Lampung Tengah. Email: leniyulinda2307@gmail.com 
tidak baik ketika mencuci tangan sebelum makan dimana mereka tidak mencuci tangan dengan sabun dan menggosok sela-sela jari dan kuku sehingga kuman sehingga ada kemungkinan kuman Salmonella typhi masih ada di bagian tersebut, selain itu hal tersebut juga dapat terjadi jika mereka tidak mencuci tangan di air mengalir tetapi di wadah. Padahal mencuci tangan yang benar haruslah menggunakan sabun, menggosok selasela jari dan kuku menggunakan air mengalir.

Hasil penelitian diperoleh sebagian responden yang memiliki hand hygiene dalam kategori tidak baik namun tidak mengalami demam tifoid $(41,9 \%)$. Selain itu responden yang memiliki hand hygiene dalam kategori baik namun masih mengalami demam tifoid $(22,6 \%)$. Hal ini dikarenakan demam tifoid dipengaruhi oleh faktor lain selain hand hygiene, misalnya yaitu demam tifoid dipengaruhi oleh kebiasaan responden dalam mengkonsumsi makanan, dimana kemungkinan demam tifoid disebabkan karena kebiasaan mengkonsumsi makanan yang tidak baik seperti tidak memasak makanan sendiri, sering jajan diuar yang tidak terjamin kebersihannya, dan lain sebagainya.

\section{SIMPULAN}

Tidak ada hubungan antara makanan tidak higienis dengan kebersihan tangan sebagai faktor risiko terjadinya demam tifoid di Bandar Jaya Lampung ( $p$-value $=0.639, \mathrm{OR}=1.23$ ); kebersihan tangan dan demam tifoid $(p$-value $=0.809, \mathrm{OR}=$ 1.24).

\section{SARAN}

Diharapkan masyarakat dapat memperbaiki kebiasaan makan dan hand hygiene agar mencegah dampak dari demam tifoid yang akan terjadi. Serta perlunya mengikuti penyuluhan yang diadakan oleh petugas kesehatan.

\section{DAFTAR PUSTAKA}

Anik, M. (2013). Perilaku Hidup Bersih dan Sehat (PHBS).Jakarta: TransInfo Media.

Budiyanto, M. A. K. (2010). Dasar-dasar ilmu gizi. Universitas Muhammadiyah Malang. Malang.
Crump, J. A., Luby, S. P., \& Mintz, E. D. (2004). The global burden of typhoid fever. Bulletin of the World Health Organization, 82, 346-353.

Dinas Kesehatan Lampung Tengah. (2018). Prevalensi Demam Tifoid. Lampung Tengah: Dinas Kesehatan Lampung Tengah.

Dinas Kesehatan Lampung Tengah. (2018). Profil Kesehatan Puskesmas Bandar Jaya. Lampung Tengah: Dinas Kesehatan Lampung Tengah.

Dinas Kesehatan Provinsi Lampung. (2018). Jumlah Pasien Rawat Inap Provinsi Lampung Berdasarkan Penyakit Menular. Bandar Lampung: Dinas Kesehatan Provinsi Lampung.

Elisabeth Purba, I., Wandra, T., Nugrahini, N., Nawawi, S., \& Kandun, N. (2016). Program pengendalian demam tifoid di Indonesia: tantangan dan peluang. Media Penelitian dan Pengembangan Kesehatan, 26(2), 99-108.

Hadinegoro, S. R., Kadim, M., Devaera, Y., Idris, N. S., \& Ambarsari, C. G. (2012). Update Management of Infectious Diseases and Gastrointestinal Disorders. Jakarta: Fakultas Kedokteran Universitas Indonesia Departemen IImu Kesehatan Anak. prevention of postoperative nausea and vomiting, Europian Journal of Anaesthesiology, 15, 69-79.

Kementerian Kesehatan Republik Indonesia. (2006). Keputusan Menteri Kesehatan Republik Indonesia Nomor 364/menkes/sk/v/2006 tentang Pedoman Pengendalian Demam Tifoid Menteri Kesehatan Republik Indonesia. Jakarta: Menteri Kesehatan Republik Indonesia.

Kementerian Kesehatan Republik Indonesia. (2014). Peraturan Menteri Kesehatan Republik Indonesia Nomor 5 Tahun 2014 Tentang Panduan Praktik Klinis Bagi Dokter Di Fasilitas Pelayanan Kesehatan Primer.

Eka Trismiyana" Program DIIl Keperawatan Fakultas Kedokteran Universitas Malahayati Email: ekatrismiyana@gmail.com Leni Yulinda Kesuma Agung', Puskesmas Bandar Jaya Lampung Tengah. Email: leniyulinda2307@gmail.com 
Kementerian Kesehatan Republik Indonesia. (2014). Pusat data dan informasi. Jakarta: Depkes RI.

Kementerian Kesehatan Republik Indonesia. (2017). Data dan informasi profil kesehatan Indonesia 2016. Jakarta: Pusdatin Kementerian Kesehatan Republik Indonesia.

Mansjoer, A. (2001). Kapita selekta kedokteran edisi ketiga. Jakarta: Media Aesculapius.

Masnawati, A. (2014). Hubungan pola makan dengan kejadian tifoid pada santri di Pondok Pesantren Tebuireng Jombang. Jurnal Metabolisme Vol. 3 No. 2 April 2014, 3(2).

Nadyah, N. (2013). Hubungan Faktor-faktor Yang Mempengaruhi Insidens Penyakit Demam Tifoid Di Kelurahan Samata Kecamatan Somba Opu Kabupaten Gowa. Jurnal Kesehatan UIN Alauddin, 7(1).

Nuruzzaman, H., \& Syahrul, F. (2016). Risk Analysis of Typhoid Fever Based on Personal Hygiene and Street Food Consumption Habit at Home. Jurnal Berkala Epidemiologi,4(1), 74-86.
Rakhman, A. (2009). Faktor-faktor risiko yang berpengaruh terhadap kejadian demam tifoid pada orang dewasa:: Studi kasus kontrol pada pasien rawat inap Rumah Sakit Dr. $H$. Soemarno Sosroatmodjo Kabupaten Bulungan Propinsi Kalimantan Timur (Doctoral dissertation, Universitas Gadjah Mada).

Santoso, S., \& Ranti, A. L. (2013). Kesehatan dan gizi.Jakarta: Rineka Cipta.

Syafrudin, T. (2009). IImu Kesehatan Masyarakat Untuk Mahasiswa Kebidanan. Jakarta: CV. Trans Info Media.

Zulfian, Z., \& Rafie, R. (2014). Hubungan personal hygiene dengan kejadian demam tifoid pada anak yang dirawat di bangsal anak RSUD Dr $\mathrm{H}$ Abdul Moeloek Provinsi Lampung Tahun 2013. Jurnal IImu Kedokteran dan Kesehatan, 1(4). 